\title{
A method for the isolation of human gastric mucous epithelial cells for primary cell culture: A comparison of biopsy vs surgical tissue
}

\author{
Michael J. Rutten ${ }^{1}$, Donald R. Campbell ${ }^{2}$, Cheryl A. Luttropp ${ }^{1}$, Wendy M. Fowler ${ }^{1}$, \\ Mitchell A. Hawkey ${ }^{1}$, C. Richard Boland ${ }^{3}$, Eugene R. Kraus ${ }^{3}$, Brett C. Sheppard ${ }^{1}$, \\ Richard A. Crass ${ }^{1}$, Karen E. Deeveney ${ }^{1} \&$ Clifford W. Deveney ${ }^{1}$ \\ ${ }^{1}$ VA Medical Center, and Department of Surgery, Oregon Health Sciences University, Portland, Oregon; \\ ${ }^{2}$ VA Medical Center, Kansas City, and Department of Medicine, University of Kansas Medical Center, Kansas City; \\ ${ }^{3}$ Department of Medicine, University of Michigan Medical School, Ann Arbor, Michigan, USA
}

Accepted in revised form 27 October 1996

\begin{abstract}
We have developed a method for the isolation and growth of normal human gastric mucous epithelial cells using biopsies or surgically resected tissues as the source of the cells. The attachment and growth of cells were dependent upon: (1) cell planting density, $\sim 50,000$ cells $/ \mathrm{cm}^{2}$; (2) extracellular matrix (fibronectin); and (3) and the use of a porous filter. In all experiments we found better cells attachment and growth of human gastric mucous cells isolated from surgical specimens compared with those gastric mucous cells isolated from gastric biopsies. The initial cell viability (as measured by Trypan-blue) was the same in both populations of gastric mucous epithelial cells isolated from either gastric biopsies or surgical specimens. After 4-5 days in culture one could detect various amounts of
\end{abstract}

mucin in all the cells using either periodic acid Schiff (PAS) staining or a spccific anti-mucin antibody. A similar pattern of much straining was also found in primary cultures of guinea pig gastric mucous epithelial cells. Immunohistochemical staining for chief cells (anti-pepsinogen) or parietal cells (anti- $\mathrm{H}^{+} / \mathrm{K}^{+}$ ATPasc) in the gastric mucous cuboidal-like epithelial cells with tight junctions, desmosomes, short microvilli, a filamentous terminal web, mucous granules, and basal lamina-like structure. We could not detect the presence of fibroblasts during the 7-9 days that the primary cells were in culture. This cell culture method will prove useful in the isolation of normal human gastric mucous epithelial cells for in vitro studies of gastric mucosal injury and repair.

Key words: Cell culture, Gastric mucosa, Human cells, Mucous epithelial cells, Stomach

\section{Introduction}

Several methods have been reported on the isolation of cells from the gastric mucosa of animals for cell culture $[2,4,6,8-11,16,19-21,24,25,27,29,31$. $36,37,40,41]$. However, the successful isolation and culture of human gastric mucous epithelial cells has been difficult because of the production of a mixed cells population [24]. One study has reported the culturing of human gastric parietal cells, but they noted extensive fibroblast overgrowth in this preparation [21]. Other investigators have also reported the isolation of human gastric epithelial cells from endoscopic biopsies for primary culture [37]. A major limitation, though, of using endoscopic biopsies is the lack of obtaining sufficient cell numbers for plating and use in multiple cell culture experiments. The MKN-28 human gastric epithelial cell line has been used in some experiments [28, 39], but these cells are derived from gastric cancer cells and still possess tumor characteristics [1, 39]. Since the population of these studies, there have been several advances in the use of dissociation media, hormones, and extracellular matrixes for the isolation, and growth of epithelial cells. For example, we now know from other tissue studies that the successful growth and differentiation of epithelial cells is dependent upon cell planting density and the use of the appropriate media $[7,13,15,17,34]$. It is also widely recognized that most cells in vivo secrete endogenous growth factors in quantities sufficient to stimulate their own proliferation (autocrine proliferation) $[3$, $14,18,39$ ]. These same phenomena are also likely to take place with cells in culture when the correct media conditions are present.

In the present study, we were particularly interested in developing a procedure for the isolation and culturing of human gastric mucous epithelial cells. It is the gastric mucous epithelial cell that is most involved in maintaining gastric mucosal barrier function $[12,14,18]$. We herein report a method using gastric surgical tissuc and gastric biopsies for the isolation of viable human gastric mucous epithelial cells for primary cell culture. In some 
experiments we also compared the primary human gastric mucous epithelial cell cultures with a previously established technique for isolating and culturing guinea pig gastric mucous epithelial cells $[27,29]$.

\section{Materials}

A. Equpiment

1. Incubator, $\mathrm{CO}_{2}$, model No. 3193 .

2. Laminar flow hood, model No. NU-425$400 .^{2}$

3. Microscope, inverted, with brightfield and fluorescence attachments, model Diaphot. ${ }^{3}$

4. Cenetrifuge, model No. GPR. ${ }^{4}$

5. Shaker bath, model No. $50 .{ }^{5}$

6. Water purification system, model No. MilliQ-RO-10-plus. ${ }^{6}$

7. Cell counter, model No. $\mathrm{ZM}^{7}$

8. DNA mini-fluorimeter, model No. TKO100.8

B. Cell culture medium

1. Dulbecco's modified Eagle's medium (DMEM) $44 \mathrm{mM} \mathrm{HCO}_{3}^{-}, 25 \mathrm{mM}$ gluoce, and $4 \mathrm{mM}$ glutamine Cat. No. 11965-050. ${ }^{9}$

2. Dulbecco's modified Eagle's medium: 44 $\mathrm{mM} \mathrm{HCO}_{3}^{-}, 25 \mathrm{mM}$ HEPES, $25 \mathrm{mM}$ glucose, and $4 \mathrm{mM}$ glutamine, Cat. No. $12430-054 .^{9}$

3. Dulbecco's modified Eagle's medium/ham F12: $15 \mathrm{mM} \mathrm{HCO}_{3}^{-}, 15 \mathrm{mM}$ HEPES, $17.5 \mathrm{mM}$ gluocse, $2.5 \mathrm{mM}$ glutamine Cat. No. 11330$024{ }^{9}$

4. RPMI: $25 \mathrm{mM} \mathrm{HCO}_{3}^{-}, 25 \mathrm{mM}$ HEPES, 11 $\mathrm{mM}$ glucose, $2 \mathrm{mM}$ glutamine, Cat. No. 22400-055. ${ }^{9}$

C. Cell culture reagents

1. Penicillin/streptomycin, Cat. No. $15145-014 .^{9}$

2. Gentamicin, Cat. No. $15750-011.9$

3. Fungizone (amphotericin-B), Cat. No. 15295$017 .{ }^{9}$

4. Collagenase (Type-I), Cat. No. C-0130. ${ }^{10}$

5. Bovine serum albumin powder, RIA-grade, Cat. No. A-7888. ${ }^{10}$

6. Trypsin/EDTA, Cat. No. $15400-054 .^{9}$

7. Vitamins, Cat. No. $21040-050 .^{9}$

8. Amino acids, Cat. No. 11130-051. ${ }^{9}$

9. Phosphate-buffered saline, Cat. No. 14080$014 .^{9}$

10. TCM, serum-free supplement, Cat. No. 1001."

11. Epidermal growth factor (human recombinant EGF), Cat. No. G-5021.12

12. Transforming growth factor-alpha (human recombinant TGF $\alpha$ ), Cat. No. G-5221. ${ }^{12}$

13. Fetal bovine serum (characterized), Cat. No. A-1115. ${ }^{13}$

14. Percoll cell separation media, Cat. No. 170891-01. ${ }^{14}$
15. Hank's balanced salt solution (10X), Cat. No. $\mathrm{H}-4385 .^{10}$

D. Complete medium: B1 media or B2 media or B3 media with the following reagents:

1. Penicillin/streptomycin, Cat. No. 15145-014. ${ }^{9}$

2. Gentamicin, Cat. No. $15750-011 .^{9}$

3. Fungizone (amphotericin-B), Cat. No. 15295$017 .^{9}$

4. Vitamins, Cat. No. $21040-050{ }^{9}$

5. Amino acids, Cat. No. 11130-051. ${ }^{9}$

6. TCM, serum-free supplement, Cat. No. 1001."

7. Epidermal growth factor (human recombinant EGF), Cat. No. G-5021. ${ }^{12}$

8. Fetal bovine serum (characterized), Cat. No. A-1115. ${ }^{13}$

E. Serum-free culture media. B1 media and all the ingredients in ' $\mathrm{D}$ ' minus the $10 \%$ FBS.

F. Cell culture growth matrices

1. Porous filter, Falcon Cyclopore insert (Cat. No. 3095), Cat. No. 08-770.5

2. Porous filter, Corning Transwell-COL insert (Cat. No. 3427), Cat. No. 07-200-153. ${ }^{5}$

3. Porous filter, Whatman Anocell (Cat. No. 6838-0148), Cat. No. 09-926-43. ${ }^{5}$

4. Porous filter, Millicell-CM, Cat. No. PICM$012-50 .^{6}$

5. Porous filter, coated with fibronectin, Becton-Dickinson (Cat. No. 40445), Cat. No. 08-774-74. ${ }^{5}$

6. Porous filter, coated with Matrigel, BectonDickinson (Cat. No. 40447), Cat. No. 08774-118.

7. Porous filter, coated with Type-IV collagen, Becton-Dickinson (Cat. No. 40565), Cat. No. 08-774-22. ${ }^{5}$

8. Porous filter, coated with Type-I collagen, Becton-Dickinson (Cat. No. 40444), Cat. No. 08-774-19. ${ }^{5}$

9. Porous filter, coated with laminin, BectonDickinson (Cat. No. 40446), Cat. No. 08774-99. ${ }^{5}$

10. Fibronectin, human, Cat. No. $688-851 .^{16}$

G. Plastic and glassware

1. Pipette, $10 \mathrm{ml}$, disposable (Falcon, Cat. No. 7551), Cat. No. 13-675-20.5

2. Pipette, $5 \mathrm{ml}$, disposable (Falcon, Cat. No. 7543), Cat. No. 13-675-22. ${ }^{5}$

3. Pipette, $1 \mathrm{ml}$, disposable (Falcon, Cat. No. 7520), Cat. No. 13-675-15C. ${ }^{5}$

4. Tissue culture plate, 12-multiwell (Falcon, Cat. No. 3503), Cat. No. 08-771-22. ${ }^{5}$

5. Tissue culture plate, 24-multiwell (Falcon, Cat. No. 3504), Cat. No. 08-771-25. ${ }^{5}$

6. Tissue culture plate, 24-multiwell (Corning/ Costar, Cat. No. 3524), Cat. No. 07-200$84 .^{5}$

7. Tissue culture flask, $75 \mathrm{~cm}^{2}$ (Corning, Cat. No. 25110-75), Cat. No. 10-126-31. ${ }^{5}$ 
8. Tissue culture Erlenmyer flask, $125 \mathrm{ml}$ (Kimble, Cat. No. 26505-125), Cat. No. 10093a. ${ }^{5}$

9. Centrifuge tube, $16 \times 125 \mathrm{~mm}$ (Falcon, Cat. No. 2037), Cat. No. 14-959-42. ${ }^{5}$

10. Centrifuge tube (Corning Cat. No. 2532550), Cat. No. 05-526B. ${ }^{5}$

11. Collagen, rat tail, Cat. No. 1-179-179. ${ }^{16}$

12. Siliconizing solution, Cat. No. SL-2. ${ }^{10}$

13. Isotonic diluent, Hematall, Cat. No. CS606$20 \mathrm{D}^{7}$

H. Histochemistry

1. Fixative, light microscopy, $37 \%$ formaldehyde solution, Cat. No. F-1635. ${ }^{10}$

2. Glutaraldehyde, $70 \%$ grade-1, Cat. No. G7776. ${ }^{10}$

3. Osmium tetroxide, $4 \%$ solution, Cat. No. O0631. ${ }^{10}$

4. Paraformaldehyde, Cat. No. P-6148. ${ }^{10}$

5. Methanol, Cal. No. M-3641. ${ }^{10}$

6. Periodic acid schiff diagnostic kit, Cat. No. 395-B. ${ }^{10}$

7. Light-green SF dye, Cat. No. L- $1886 .^{10}$

8. Methylene blue, Cat. No. M-9140. ${ }^{10}$

9. Basic fuchsin, Cat. No. B-0904. ${ }^{10}$

10. Thiocarbohydrazide, Cat. No. T-2137. ${ }^{10}$

11. Anti-cytokeratin antibody, Cat. No. C-5301. ${ }^{10}$

12. Anti-vimentin antibody, Cat. No. V- $6630 .^{10}$

13. Goat-antirabbit antibody, Cat. No. A-0545. ${ }^{10}$

14. Goat-antimouse antibody, Cat. No. P-2416. ${ }^{10}$

15. Triton, Cat. No. $\mathrm{X}-100 .^{10}$

16. Embedding media, LR-White, Cat. No. LRW-M. ${ }^{10}$

17. Cover slips, Corning 1 (Cat. No. 2865-18), Cat. No. 12-524A. ${ }^{5}$

18. FluorSave, fluorescent mounting medium, Cat. No. $345789 .^{15}$

19. Tissue histological mounting medium, Cat. No. BM-M01.'

I. Cell isolation equipment

1. Scalpel, disposable, handle and No. 10 blade, Cat. No. 08-927-5A. ${ }^{5}$

2. Scalpel, disposable, handle and No. 11 blade, Cat. No. 98-927-5B. ${ }^{5}$

3. Razor blades, Cat. No. $12-640 .^{5}$

4. Forceps, dissecting, Cat. No. $08-882 .^{5}$

5. Scissors, abdominal, Cat. No. $13-804-2 .^{5}$

6. Sylgard plastic. ${ }^{17}$

7. Petri dishes, $60 \mathrm{~mm}$ (Falcon, No. 1007), Cat. No. $08-757-100 \mathrm{~B}{ }^{5}$

8. Glass slides $(75 \times 25 \mathrm{~mm})$, Cat. No. $12-544-$ $7 .^{5}$

9. Screen, $200 \mu \mathrm{m}$ mesh, cell dissociation sieve, Cat. No. S-4145. ${ }^{10}$

J. Cell viability supplies

1. Trypan blue $(0.04 \%$ solution), Cat. No. T$8154 .^{10}$

2. Hemacytometer counting chamber, Cat. No. $02-671-5 .^{5}$
3. $\mathrm{pH}$ meter and $\mathrm{pH}$ electrode, Cat. No. PHM-82 Radiometer. ${ }^{19}$

K. Animals

1. Guinea pigs, either sex, 275-325 grams. $^{18}$

\section{Procedures}

A. Preparation of materials

1. Use standard sterilization techniques for all glassware, and media. Siliconize all glassware by adding $5 \mathrm{ml}$ of siliconizing solution to each piece of glassware, parafilm the top of each, swirl the siliconizing solution to coat the inside of the glassware, then pour out the solution, and air dry.

2. Cell isolation media: To $473 \mathrm{ml}$ of the DMEM/HEPES media (Cat. No. 12430-021.') add:

a) Pencillin/streptomycin (reconstitute one bottle of pen/strep with $20 \mathrm{ml}$ of the DMEM media);

b) $125 \mu \mathrm{l}$ of gentamicin (reconstituted stock $=50 \mathrm{mg} / \mathrm{ml}$ );

c) $2 \mathrm{ml}$ of fungizone;

d) $10 \mathrm{ml}$ of celox TCM supplement;

e) $10 \mathrm{ml}$ of MEM amino acids;

f) $5 \mathrm{ml}$ of BMEM of vitamin solution;

g) $50 \mathrm{ng} / \mathrm{ml}$ of epidermal growth factor;

3. Complete media: All of the above ingredients are added to $423 \mathrm{ml}$ of the various media (as outlined in Section 2-B1, B2, B3, B4) including $50 \mathrm{ml}$ of fetal bovine serum.

4. Cell isolation solutions:

a) Collagenase solution: 'To a siliconized $125 \mathrm{ml}$ screw-cap Erlenmeyer flask, add $20 \mathrm{ml}$ of serum-free culture media, $20 \mathrm{mg}$ of Type-I collagenase, and $20 \mathrm{mg} \mathrm{BSA}$ powder.

b) Iso-osmotic Percoll solution: To a $50 \mathrm{ml}$ sterile Corning centrifuge tube, mix $36 \mathrm{ml}$ of Percoll, with $4 \mathrm{ml}$ of $10 \times$ Hank's balanced salt solution, and $1.6 \mathrm{ml}$ of 0.1 $N \mathrm{HCl}$ (final osmolarity is $310 \mathrm{mosm} / 1$, density of $1.125 \mathrm{~g} / \mathrm{ml}, \mathrm{pH} 7.4$ ).

B. Isolation of human gastric mucous epithelial cells Human tissue procurement:

1. Gastric tissue obtained from patients undergoing a routine endoscopic biopsy or surgical gastrectomy (the VA and OHSU Human Studies Subcommittee approved all experimental use of human tissue).

2. After the surgical resection, all tissues $\left(\sim 4 \mathrm{~cm}^{2}\right)$ are placed in a $100 \mathrm{ml}$ beaker containing $75 \mathrm{ml}$ of $4{ }^{\circ} \mathrm{C}$ serum-free DMEM/ HEPES cell culture media. The same media is used for the gastric endoscopy samples. Place 4-6 pinch biopsies $\left(\sim 2 \mathrm{~mm}^{2}\right.$ from the same patient) intoa a $25 \mathrm{ml}$ Erlenmeyer flask 
containing $15 \mathrm{ml}$ of $4{ }^{\circ} \mathrm{C}$ serum-free media. All samples should be processed within $30 \mathrm{~min}$ after removal for best results.

Guinea pig tissue procurement:

1. Anesthetize guinea pigs with halothane and sacrifice by decapitation. Wipe the abdomen of a guinea pig with $70 \%$ ethanol. Use a scalpel with a No. 10 blade to make an incision through the abdominal skin. Use forceps to pull out the stomach, and cut the esophagus and pyloric sphincter.

2. Remove the stomach from the animal, cut the stomach into two halves along the greater, and rinse the luminal surface with sterile Millipore water to remove adherent food and mucus. Put one tissue half into serum-free culture media, and the other tissue half into $3.7 \%$ formalin. Repeat this procedure with the next guinea pig. The best results are obtained when two animals are used for cach cell isolation.

Cell isolation:

1. Tissue samples are washed twice in serumfree media by placing the specimens in $50 \mathrm{ml}$ conical tubes with $40 \mathrm{ml}$ of serum-free media and spun at $50 \times g$ for $3 \mathrm{~min}$.

2. After washing, the resected stomach samples are pinned down (luminal side of tissue facing up) with 18-gauge needles in a $60 \mathrm{~mm}$ petri dish containing polymerized Sylgard. The epithelium is then removed from the underlying muscle layers by scraping the luminal surface of the tissue with a glass slide held at a $45^{\circ}$ angle; use $2-3$ glass slides for this procedure. Transfer the scraped tissue pieces to a new $60 \mathrm{~mm}$ Sylgard Petri dish and mince them using two straight-edge razor blades. Note, we do not remove the epithelium from the underlying muscle layers on the cndoscopy samples because the samples are too small for handling.

3. Wash the minced tissue samples three times at $100 \times g$ for $3 \mathrm{~min}$ in serum-free cell culture media.

4. Put the pellets from the last wash step into a siliconized $125 \mathrm{ml}$ screw-up Erlenmeyer flask containing $20 \mathrm{ml}$ of serum-free culture media containing $20 \mathrm{mg} / \mathrm{ml}$ of Type-I collagenase with $0.1 \%$ bovine ablumin. Next, gas the flasks with $95 \% \mathrm{O}_{2}-5 \% \mathrm{CO}_{2}$ and put them into a $37^{\circ} \mathrm{C}$ shaking water bath and gyrated at 120 oscillations $/ \mathrm{min}$. Incubate the surgical specimens for $45 \mathrm{~min}$, and the gastric biopsy samples for $90 \mathrm{~min}$. Remove the flasks every $15 \mathrm{~min}$ from the incubator and triturate the digestion mixture with a $10 \mathrm{ml}$ pipette. Reoxygenate the flasks with $95 \% \mathrm{O}_{2}-5 \% \mathrm{CO}_{2}$ and put back into the incubator.

5. At the end of the final incubation period, pour the collagenase digestion mixture into a 50- $\mathrm{ml}$ syringe with an attached 15-gauge luerstub adapter. Push out the collagenase mixture from the syringe over a $200-\mu \mathrm{m}$ mesh screen. Wash the mesh-filtered suspension twice in serum-free culture media at $100 \times \mathrm{g}$ for $3 \mathrm{~min}$. Resuspended the pellet in $15 \mathrm{ml}$ of serum-free culture media, and take two $200 \mu \mathrm{l}$ aliquots for cell counts in a Coulter counter.

6. Take $5 \mathrm{ml}$ aliquots of the resuspension and mix with $5 \mathrm{ml}$ of isosmotic Percoll in Falcon $16 \times 125 \mathrm{~mm}$ tubes. Centrifuge the cell/ Percoll mixture for $15 \mathrm{~min}$ at $100 \times \mathrm{g}$ at $24^{\circ} \mathrm{C}$. At the end of this centrifiguation, cells appear at the top of the Percoll gradient and as a pellet at the bottom of the gradient. The cells at the top of the gradient contain unidgested gastric glands, parietal, and chief cells. The cells at the bottom of the Percoll gradient are gastric mucous epithelial cells. Wash the cells at the top of the gradient three times at $20 \times g$ for $3 \mathrm{~min}$ in serum-free cell culture media. Resuspended this pellet in 2ml of PBS for use later in immuno-flourescence studies. Remove the rest of the Percoll gradient, and resuspended and wash the bottom pellet three times at $20 \times g$ for $3 \mathrm{~min}$ in serum-free cell culture media. The surgical gastric specimens yield $\sim 6-9 \times 10^{6}$ gastric mucous epithelial cells, the guinea pig gastric specimens yield $\sim 3-6 \times 10^{6}$ gastric mucous epithelial cells, and the gastric biopsy's $\sim 2.5-4.0 \times 10^{5}$ gastric mucous epithelial cells.

7. A cell viability assay was done after each cell isolation using the Trypan-blue dye exclusion technique. For these studies an aliquot of 0.2 $\mathrm{ml}$ gastric cell suspension was mixed with 0.3 ml IIank's solution and $0.5 \mathrm{ml}$ of the $0.4 \%$ Trypan blue solution (1:5 dilution). The cell/dye suspension was then counted on a hemacytometer at five min after the addition of the Trypan blue. The '\% cell viability' was determined as:

$$
\frac{\text { total number of viable cells }}{\text { total number of stained and unstained cells }} \times 100 \text {. }
$$

Cell plating:

1. Resuspended the enriched pellets of gastric mucous epithelial cells in different test culture media (B1, B2, B3, B4; see above) with $10 \%$ serum.

2. Plate the cell suspensions at various densities $\left(12,500-200,000 \mathrm{cells} / \mathrm{cm}^{2}\right)$ on Costar 24multiwell dishes or on porous filters (see Section 2F.1-9). The porous filters were either uncoated or purchased with extracellular matrix coatings consisting of Type-IV collagen, fibronectin, Type-I collagen, Matrigel, and laminin.

3. For some experiments the uncoated filters 
were coated with $10 \mu \mathrm{g} / \mathrm{ml} / \mathrm{cm}^{2}$ Type-I collagen, then coated at $10 \mu \mathrm{g} / \mathrm{ml} / \mathrm{cm}^{2}$ with fibronectin.

Measurement of cell growth:

1. At various times after cell plating, $0.25 \mathrm{ml}$ of $2 \times$ trypsin/EDTA solution was added to each culture well or porous filter, followed twenty minutes later by $0.25 \mathrm{ml}$ of cell culture media with serum to stop the trypsinization. Remove the trypsinized cell suspension and centrifuge it at $50 \times \mathrm{g}$ for $3 \mathrm{~min}$, and the pellet resuspended in $1 \mathrm{ml}$ of PBS.

2. From the $1 \mathrm{ml}$ suspension take $200 \mu \mathrm{l}$ and add it to $20 \mathrm{ml}$ of Hematall for cell counts using a Coulter counter with a multi-channel particle size analyzer. The remainder of the cell suspension is used to measure DNA fluorometrically with the Hoechst-3258 dye and a Hoefer mini-fluorometer. Calf thymus DNA is used to make the standard curve.

C. Identification of mucin

1. Mucin PAS cytochemistry: Human and guinea pig intact stomach tissues are fixed in $3.7 \%$ formalin, paraffin-embedded, 4-5 micron sections cut, and deparaffinized. Rinse the sections in PBS, oxidize them for $10 \mathrm{~min}$ in $1 \%$ periodic acid, rinse once in PBS, then add Schiff's reagent for $10 \mathrm{~min}$. Remove the Schiff's reagent, then put the slides directly into three successive baths ( $\sim 2 \mathrm{~min}$ each) of $0.52 \% \mathrm{NaHSO}_{4}$ ). Rinse the sections for $10 \mathrm{~min}$ in PBS, counterstain with $0.01 \%$ Light-green solution, then cover-slipped with mounting media for microscopic visualization. The above procedure is also used for human and guinea pig gastric mucous cell cultures except the deparaffinization step.

2. Mucin immunohistochemistry: Human and guinea pig gastric mucosae are fixed in $3.7 \%$ formalin and processed for paraffin sections as described above. Treat the sections with an anti-mucin antibody $[6,32]$, at dilutions of 1:50-1:200 for two hours at $24^{\circ} \mathrm{C}$. Wash the sections three times with PBS then add a peroxidase labeled goat-antirabbit antibody at a 1:100 dilution for one hour at room temperature. Wash the slides three times with PBS, counterstain with $0.02 \%$ toluidine blue, then add mounting media and a cover-glass for microscopic visualization. The above protocol was also used for the human and guinea pig gastric mucous cell cultures without the deparaffinization step.

D. Epithelial markers and identification of cells Human gastric mucous epithelial cells are plated on 24-multiwell dishes or filter inserts and allowed to grow for four days in culture. At the end of this time, the cultures are washed once with $24{ }^{\circ} \mathrm{C}$ PBS, and fixed for $5 \mathrm{~min}$ with $3.7 \%$ formalin. Remove the fixature and rinse the cultures three times with $24^{\circ} \mathrm{C}$ PBS. The cultures are then exposed to $4{ }^{\circ} \mathrm{C}$ acetone fr $2.5 \mathrm{~min}$, rinsed four times with $24^{\circ} \mathrm{C}$ PBS for $10 \mathrm{~min}$, then treated with an anti-cytokeratin [38] or antivimentin antibody at a dilution of 1:100 for $30 \mathrm{~min}$ at $24^{\circ} \mathrm{C}$. Wash the cultures twice with PBS, then visualize the sections by the addition of a peroxidase-labeled anti-mouse antibody as described above.

E. Identification of gastric cell type using immunofluorescence

Human and guinea pig gastric glands, and human gastric mucous epithelial cell cultures (grown on Falcon filters) are fixed with $2.5 \%$ paraformaldehyde for $10 \mathrm{~min}$. Rinse the cultures and glands three times with $24{ }^{\circ} \mathrm{C}$ PBS, permeabilize with $100 \%$ methanol for $1 \mathrm{~min}$ at $4{ }^{\circ} \mathrm{C}$, wash three times with $24^{\circ} \mathrm{C}$ PBS, then treat them with $0.1 \%$ triton-PBS for $3 \mathrm{~min}$. Rinse the glands and cultures three times with $24^{\circ} \mathrm{C}$ PBS. Incubate the glands and cultures with either a poyclonal antibody against human pepsinogen-II [31, 35], or a monoclonal antibody against the hog gastric $\mathrm{H}^{+} / \mathrm{K}^{+}$-ATPase [33] at a $1: 75$ dilution at $4{ }^{\circ} \mathrm{C}$ overnight in a humidified chamber. Fetal bovine serum or goat serum is used in place of the primary antibodies for negative controls. Wash three times with $24{ }^{\circ} \mathrm{C}$ PBS and incubate the cultures and glands with: (1) a rhodamine-labeled goat anti-rabbit $\operatorname{IgG}$ at a 1:40 dilution, or (2) a rhodamine-labeled goat anti-mouse total IgG at 1:100 dilutions for 1 hour at $24^{\circ} \mathrm{C}$ in a humidified chamber. Wash the cultures and glands three times with $24{ }^{\circ} \mathrm{C}$ PBS, then add a drop of FluoroSave and examine them with a Nikon inverted microscope using with epifluorescence.

F. Morphology

1. Light microscopy: gastric cells are cultured on filter inserts precoated with fibronectin and Type-1 collagen. The gastric tissues and cultures are fixed for 24 hours in $3.0 \%$ formaldehyde, $3.0 \%$ glutaraldehyde in cacodylate buffer ( $\mathrm{pH} 7.4$ ). After fixation use a scalpel with a No. 11 blade to remove the porous filter from its plastic holder. Postifix both the filter and tissue in $1.0 \%$ $\mathrm{OsO}_{4}$ for 1 hour, dehydrate them in a graded series $(20-100 \%)$ of eethanol solutions, and embedded them in LR-White resin. Thick sections $(0.5-1.0 \mu \mathrm{m})$ are cut and stained with Lee's methylene blue/basic fuchsin. Photographs are taken with a Nikon inverted microscope using Tech-Pan $35 \mathrm{~mm}$ film at 50 ASA.

2. Electron microscopy: For convertical electron microscopy, cultures and tissues are processed as described above for light microscopy. Thin sections $(0.1-0.2 \mu \mathrm{m})$ are cut, post- 
stained with uranyl acetate/lead citrate, and photographed using a JEOL 100-CXII electron microscope. For electron cytochemical demonstration of mucoproteins, cell cultures and tissues are fixed for $10 \mathrm{~min}$ in $2.0 \%$-glutaradlehyde $/ 1.0 \mathrm{mM} \mathrm{CaCl}_{2}$ in acaodylate buffer ( $\mathrm{pH} 7.4$ ). Rinse the specimens three times in $150 \mathrm{mM} \mathrm{NaCl}$ for $3 \mathrm{~min}$, then immersed them in $1.0 \%$ periodic acid $\left(\mathrm{H}_{5} \mathrm{IO}_{6}\right)$ for $5 \mathrm{~min}$. Wash the specimens once in $150 \mathrm{mM} \mathrm{NaCl}$ for $1 \mathrm{~min}$ and then immersed in $1.0 \%$ thiocarbohydrazide in $10 \%$ acetic acid for $30 \mathrm{~min}$ at $37^{\circ} \mathrm{C}$. Rinse the specimens twice in cacodylate buffer for $5 \mathrm{~min}$, then immersed them in $1.0 \% \quad \mathrm{OsO}_{4}$ cacodylate buffer for $30 \mathrm{~min}$. Wash the specimens twice in a fresh cacodylate buffer, then embed them in LR-White resin. Thin sections are cut and directly examined or post-stained with a lead citrate solution and examined for electronopaque deposits using a JEOL-100CXII electron microscope.

G. Statistical analysis

Differences between treatment groups were compared using Student's $t$-test $(p<0.05)$. For multiple comparisons between several groups use a two or three-way analysis of variance (ANOVA). ' $\mathrm{N}$ ' is the number of separate individual cell isolations, with each experimental point done in triplicate.

\section{Results and discussion}

\section{Media, plating density, and attachment factors}

One of our first objective was to determine those conditions that would produce maximal attachment and growth of the gastric mucous epithelial cells. The media used for this part of the assay consisted for four different formulations: (1) DMEM with $44 \mathrm{mM}$ $\mathrm{HCO}_{3}^{-}, 25 \mathrm{mM}$ glucose, $4 \mathrm{mM}$ glutamine; (2) DMEM with $44 \mathrm{mM} \mathrm{HCO}_{3}^{-}, 25 \mathrm{mM}$ HEPES, $25 \mathrm{mM}$ glucose, $4 \mathrm{mM}$ glutamine; (3) DMEM/Ham F-12 with $15 \mathrm{mM}$ $\mathrm{HCO}_{3}^{-}, 15 \mathrm{mM}$ HEPES, $17.5 \mathrm{mM}$ glucose, $2.5 \mathrm{mM}$ glutamince; (4) RPMI with $25 \mathrm{mM} \mathrm{HCO}_{3}^{-}, 25 \mathrm{mM}$ HEPES, $11 \mathrm{mM}$ glucose, $2 \mathrm{mM}$ gluatmine. To standardize the $\mathrm{pH}$ effects of the bicarbonate and HEPES components in each media, the media were equilibrated under different $\mathrm{CO}_{2}$ tensions as indicated in Table 1 . Before plating, the viability of the gastric mucous epithelial cells was checked using a Trypanblue dye solution. We found no significant difference $(p>0.05)$ in the viability of those gastric mucous epithelial cells isolated from biopsy specimens as compared to surgical tissues (Table 2). The results of plating the gastric mucous epithelial cells at $100,000 \mathrm{cells} / \mathrm{cm}^{2}$ on plastic culture dishes is shown in Figure 1. We found media Formulation 2 gave the best results as to the number of viable cells attached after 48 hours (Figure 1). We also found a greater growth in all of the media with cells isolated from surgical specimens compared with those cells isolated from gastric biopsies (Figure 1). We also examined the initial cell plating density and how it affects the rate of cell growth. As shown in Figure 2, a significant difference was found in the plating efficiency

Table 1. Bicarbonate, HEPES, and $\mathrm{pH}$ values of the media used

\begin{tabular}{lllll}
\hline Media & $\begin{array}{l}\text { [bicarbonate } \\
(\mathrm{mM})\end{array}$ & $\begin{array}{l}\text { [HEPES }] \\
(\mathrm{mM})\end{array}$ & $\% \mathrm{CO}_{2}$ & final pH \\
\hline $\begin{array}{l}\text { DMEM } \\
\text { (Gibco } 1 \text { 1965-050) }\end{array}$ & 44 & 0 & 8 & $7.49 \pm 0.04$ \\
$\mathrm{~N}=5$ & & & 5 & $7.46 \pm 0.03$ \\
$\begin{array}{l}\text { DMEM } \\
\text { (Gibco } 12430-021)\end{array}$ & 44 & 25 & & \\
$\mathrm{~N}=5$ & & & 5 & $7.37 \pm 0.02$ \\
$\begin{array}{l}\text { DMEM } \\
\text { (Gibco } 11330-024)\end{array}$ & 15 & 15 & & \\
$\mathrm{~N}=5$ & & & 5 & $7.41 \pm 0.02$ \\
$\begin{array}{l}\text { RPMI } \\
\text { (Gibco 22400-055) }\end{array}$ & 25 & 25 & & \\
$\mathrm{~N}=5$ & & & 5 & \\
\hline
\end{tabular}

The reported $\mathrm{pH}$ measurements were determined after 24 hours equilibration in the $\% \mathrm{CO}_{2}$ indicated above using $2 \mathrm{ml}$ of media/well in 6-multiwell dishes within the same area of the incubator. It should be noted that a $25 \mathrm{mM}$ HEPES buffer with no bicarbonate equilibrated with $5 \% \mathrm{CO}_{2}$ gave us a $\mathrm{pH}$ of $6.96 \pm 0.02 . \mathrm{N}$ is the number of individual $\mathrm{pH}$ experiments performed in triplicate using the above media formulations. 
Tahle 2. Viability of isolated gastric mucous epithelial cells after cell isolation

\begin{tabular}{ll}
\hline $\begin{array}{l}\text { Cells isolated from } \\
\text { biopsy samples }\end{array}$ & $\begin{array}{l}\text { Cells isolated from } \\
\text { surgical specimens }\end{array}$ \\
\hline $94 \pm 3.1$ & $93 \pm 2.8$ \\
$\mathrm{~N}=12$ & $\mathrm{~N}=12$ \\
\hline
\end{tabular}

The values are the percentage of live cells (cells that excluded the Trypan blue dye). $\mathrm{N}$ is the number of separate individual cell isolations, with each experimental point done in triplicate.

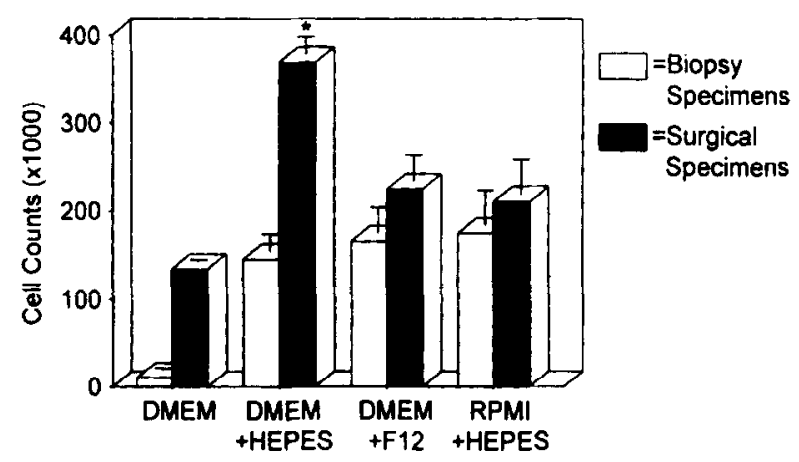

Figure 1. The effects of different media formulations on the growth of the human gastric mucous epithelial cells. The gastric mucous epithelial cells were isolated from gastric biopsies or gastric surgical specimens and plated at 50,000 cells $/ \mathrm{cm}^{2}$ in 24-multiwell dishes containing: (1) Dulbecco's modified Eagle's medium; (2) Dulbecco's modified Eagle's medium with $25 \mathrm{mM}$ HEPES; (3) Dulbecco's modified Eagle's medium with Ham F-12; (4) RPMI with $15 \mathrm{mM}$ HEPES. The media was changed on the second day after plating, and the cells trypsinized and counted two days later (total of four days in culture). Note the differences in growth with the various media between gastric mucous cells isoalted from gastric biopsies vs. surgical specimens. The * denotes significantly different $(p<0.05)$ from other media formulations for the surgical specimens. Each point is the mean $\pm \mathrm{SEM} . \mathrm{N}=8$, which is the number of separate individual cell isolations, with each experimental point done in triplicate.

between mucous epithelial cells isolated from gastric biopsies and those obtained from surgical specimens. The optimal plating density for gastric mucous epithelial cells isolated from biopsy and surgical tissue was $\sim 100,000$ cells $/ \mathrm{cm}^{2}$ and $\sim 50,000$ cells/ $\mathrm{cm}^{2}$, respectively.

Cell attachment and growth were also assayed using five different matrix factors: (1) fibronectin; (2) Matrigel; (3) Type-IV collagen; (4) Type-I collagen; (5) laminin. For gastric mucous epithelial cells isolated from surgical specimens, we found that fibronectin $>$ Type-I collagen $>$ plastic $>$ laminin in the number of attached gastric mucous epithelial cells was the preferred matrix pattern (Figure 3). A similar pattern of gastric cell attachment was also found when the cells were plated under serum-free conditions (data not shown). We also found more growth

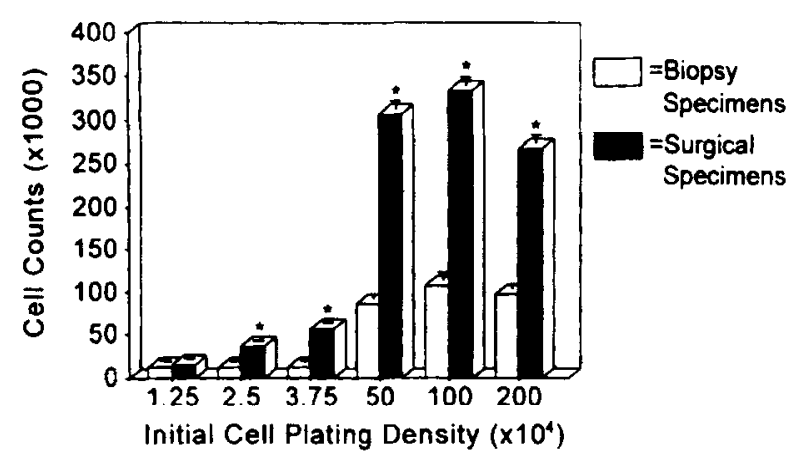

Figure 2. Gastric mucous epithelial cells were isolated from gastric biopsies or gastric surgical specimens, resuspended in DMEM $/ 25 \mathrm{mM}$ HEPES with $10 \%$ FCS and plated in plastic 24-multiwell dishes at: $12,500 \mathrm{cells} / \mathrm{cm}^{2}$; 25,000 cells $/ \mathrm{cm}^{2} ; 37,500$ cells $/ \mathrm{cm}^{2} ; 50,000$ cells $/ \mathrm{cm}^{2}$; $100,000 \mathrm{cells} / \mathrm{cm}^{2}$; and 200,000 cells $/ \mathrm{cm}^{2}$. The cells were trypsinized and counted four days later with a change of media on day two. Note the differences in plating efficiency between gastric mucous cells isolated from gastric biopsies vs. surgical specimens. The * denotes that the surgical specimen cell counts were significantly different $(p<0.05)$ from the biopsy specimen cell counts. Each point is the mean \pm SEM. $N=4$, which is the number of separate individual cell isolations, with each experimental point done in triplicate.

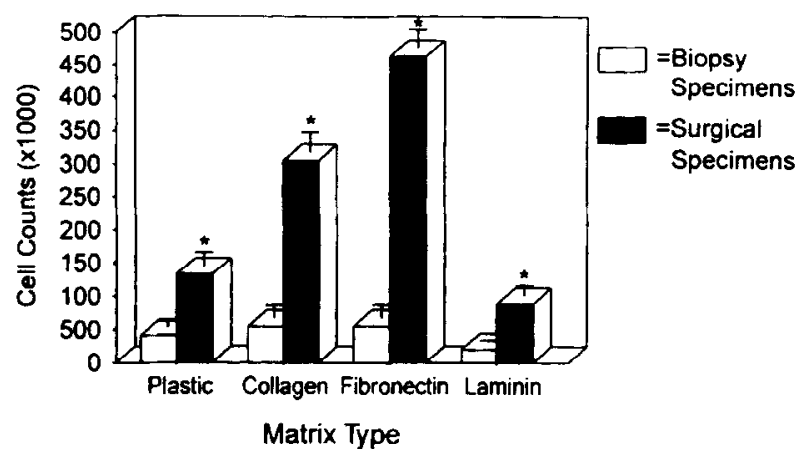

Figure 3. A graph showing the attachment and growth of human gastric mucous epithelial cells obtained from surgical tissue using four different matrix factors. The * denotes that the surgical specimen cell counts were significantly different $(p<0.05)$ from the biopsy specimen cell counts within each matrix category. Each point is the mean \pm SEM. $N=9$, which is the number of separate individual cell isolations, with each experimental point done in triplicate.

from those gastric mucous epithelial cells isolated from surgical specimens compared with cells isolated from the gastric biopsies (Figure 3 ). We should note that both Matrigel and Type-IV collagen promoted no growth of gastric mucous epithelial cells isolated from either the surgical or biopsy specimens when plated under serum or serum-free conditions (unpublished observations).

Our next objective was to find out the attachment ability of the cells to various cell culture inserts. Using gastric mucous epithelial cells isolated from surgical specimens, we found that Falcon, Costar, and 
Anotec uncoated porous filters were similar in cell attachment and doubling times for these cells (Table $3)$. The one exception in this category was the uncoated Millipore-CM insert, where very few cells were found attached after four days in culture (Table 3 ). When we coated the Falcon, Costar, and Anotec porous filters with fibronectin, we found cell attachment and doubling times were nearly identical (Table 3). The attachment and doubling time also increased for fibronectin-coated Millipore CM inserts, but were still less than the other fibronectin-coated filters (Table 3). Of the commercially available filter inserts tested, we found the uncoated or fibronectin-coated Falcon inserts produced the maximal growth rate. Similar qualitative results were also obtained using cells isolated from gastric biopsy samples, but the low cellular yield from these tissue samples did not allow us to do as many replicates of these experiments as reported above with the cells isolated from surgical specimens (data not shown).

\section{Morphology: cytokeratin, vimentin, PAS and mucin histochemistry}

At the light microscopic level, gastric mucous epithelial cells cultured on fibronectin-coated filters had tightly packed colonies of PAS-positive, polygonalshaped cells producing a 'cobblestone' appearance (Figure 4A). We found that all cells in the monolayer stained positively for the epithelial marker cytokeratin (Figure 4B), and negative for the fibroblast marker vimentin (Figure $4 \mathrm{C}$ ). To characterize the identity of our cultures further, we used three standard gastric epithelial markers: (1) an anti-mucin antibody for mucous cells; (2) an anti- $\mathrm{H}^{+} / \mathrm{K}^{+}$ATPase for parietal cells; and (3) an anti-pepsinogen antibody for chief cells. With the anti-mucin antibody, we found positive immunoreactivity in gastric surface and mucous neck epithelial cells in paraffin sections of guinea pig (Figure 5A, B) and human (Figure 5C, D) gastric mucosae. We could also detect positive immunoreactivity with the anti-mucin antibody in both the guinea pig (Figure 6A) and human (Figure 6C) gastric mucous epithelial cells cultures. We could see no positive immunostaining in the cultured cells without the primary antibody (Figure 6B, D). Using the anti- $\mathrm{H}^{+} / \mathrm{K}^{+}$-ATPase antibody, or the anti-pepsinogen antibody, we could clearly identify positive immunostaining in parietal (Figure 7B) and chief (Figure 7C) cells, respectively. However, in the human gastric mucous epithelial cell cultures, we found no immunofluorescence with either the anti$\mathrm{H}^{+} / \mathrm{K}^{+}$-ATPase antibody (Figure $7 \mathrm{E}$ ) or the antipepsinogen antibody (Figure 7F). These results suggest the absence of parietal and chief cells in our cell cultures.

\section{Morphology: electron microscopy}

A representative low power electron-micrograph of a human gastric mucous epithelial cell culture grown on a fibronectin-coated Falcon filter (Figure 8A). We found the cell culture monolayers to consist of a single layer of polarized cuboidal epithelial cells with apically located mucous granules, short apical microvilli, and tight junctions in these cultures (Figure 8B). We could positively identify these apically located granules as containing mucin when we treated the cultures with $\mathrm{H}_{5} \mathrm{IO}_{6}$ with $\mathrm{TCH}$ and osmium for the electrochemical identification of mucin (Figure 9). In many cultures we could also identify a basal lamina-like structure, microfilaments associated with apical microvilli, and tight junctions (Figure 9).

Table 3. Growth rates of human gastric mucous epithelial cells isolated from surgical tissues plated on commercially available cell culture inserts

\begin{tabular}{lllll}
\hline Cell culture filter & $\begin{array}{l}\text { Uncoated filter } \\
(\% \text { attachment })\end{array}$ & $\begin{array}{l}\text { Unocated filter } \\
\text { doubling time } \\
\text { (days) }\end{array}$ & $\begin{array}{l}\text { Coated filter } \\
\text { (\% attachment) }\end{array}$ & $\begin{array}{l}\text { Coated filter } \\
\text { doubling time } \\
\text { (days) }\end{array}$ \\
\hline $\begin{array}{l}\text { Falcon inserts } \\
\mathrm{N}=18 / 3\end{array}$ & 79.1 & 2.90 & 91.2 & 2.52 \\
$\begin{array}{l}\text { Costar transwell-COL } \\
\text { inserts }\end{array}$ & 62.3 & 3.44 & 85.3 & 2.69 \\
$\mathrm{~N}=18 / 3$ & & & 2.65 \\
$\begin{array}{l}\text { Anotec inserts } \\
\mathrm{N}=18 / 3\end{array}$ & 66.7 & 3.68 & 86.6 & 4.24 \\
$\begin{array}{l}\text { Millipore CM inserts } \\
\mathrm{N}=12 / 3\end{array}$ & 1.4 & $>25$ & 54.2 & \\
\hline
\end{tabular}

Fibronectin coated cell culture inserts (Falcon) were used in these studies. $\mathrm{N}$ is the total number of filters divided by the total number of individual cell isolations. 

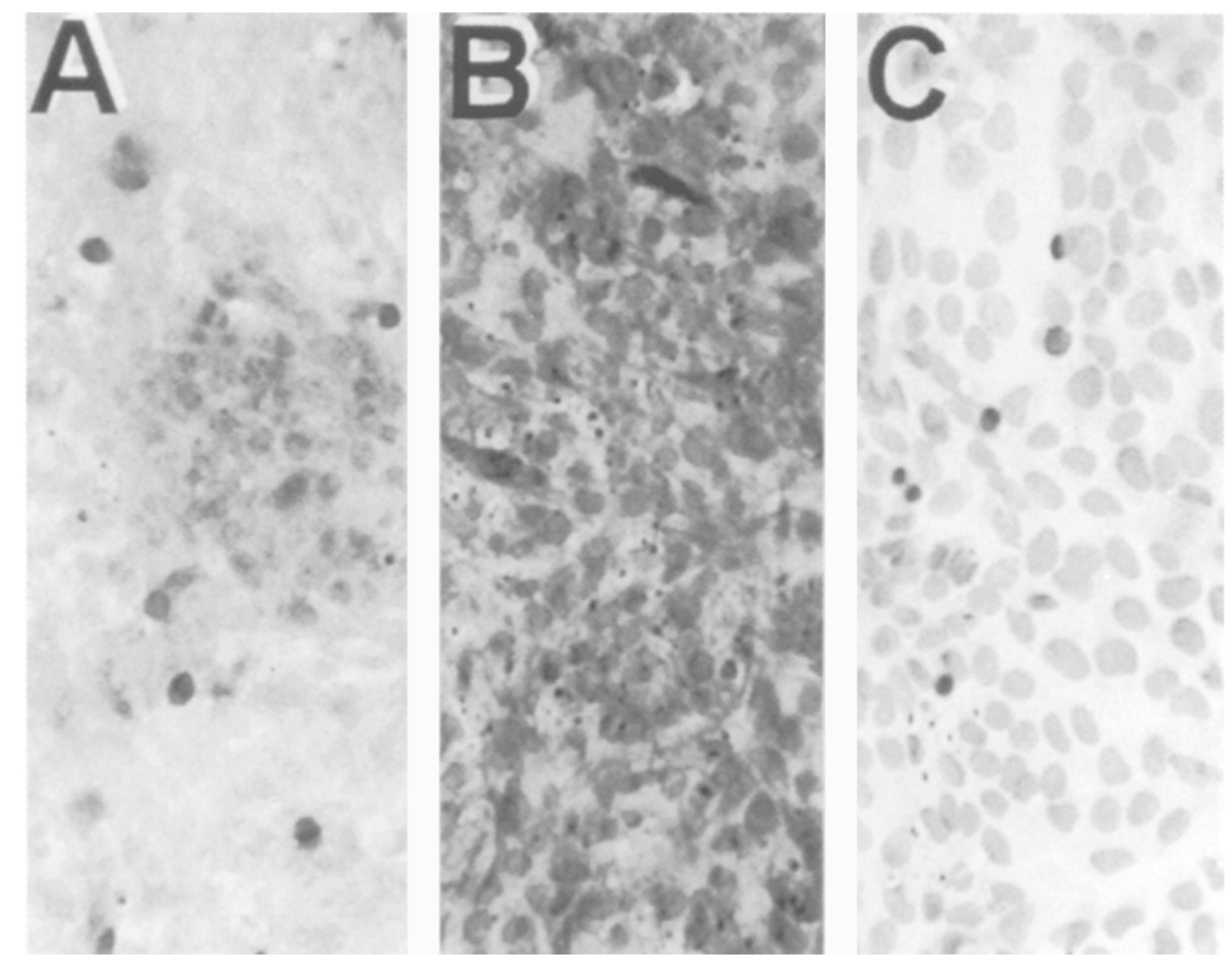

Figure 4. Figure 4 is a series of photographs showing the cytochemical staining of human gastric mucous epithelial cell cultures prepared from cells isolated from surgical specimens and grown on fibronectin-coated filters. A is a photograph showing PAS-positive staining of cells that have a typical cobblestone-like appearance. B shows gastric mucous epithelial cells staining positively for the epithelial marker cytokeratin. $\mathrm{C}$ shows gastric mucous epithelial cells that stained negatively for the fibroblast markre vimentin. $\times 200$.
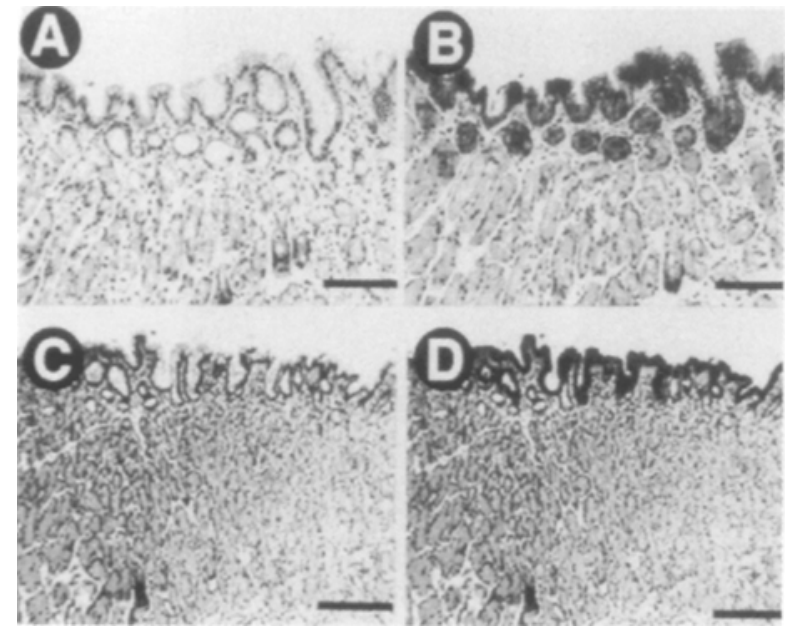

Figure 5. Light micrographs showing the presence of mucin in sections of intact guinea pig (A, B) and human (C, D) gastric mucosa. Using a specific anti-mucin antibody we found positive reactivity primarily in the gastric surface and some mucous neck epithelial cells (B, D). There was no reactivity in the control sections of both tissue types $(A, C)$. Bar, $100 \mu \mathrm{m}$.

\section{Final culture conditions}

We found that gastric mucous epithelial cells isolated from surgical specimens were twice as likely to attach, grow, and form monolayers as compared with
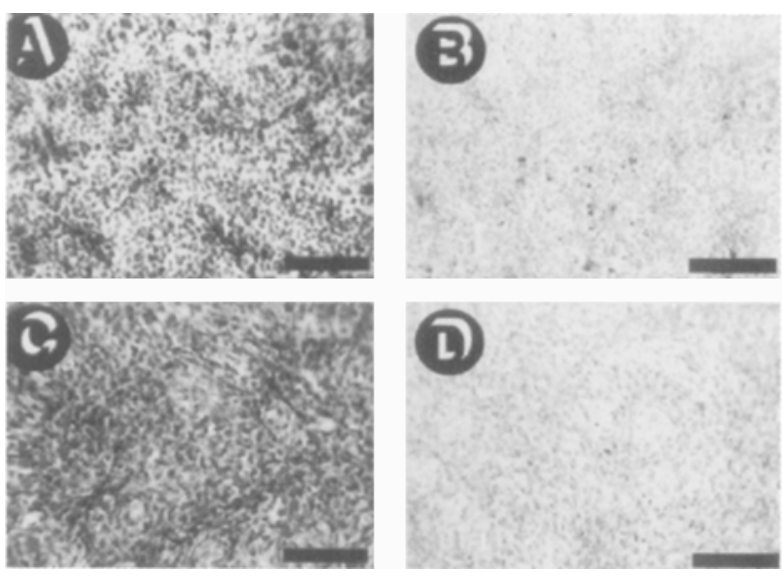

Figure 6. Light micrographs showing the presence of mucin in primary cultures of guinea pig (A) and human (C) gastric mucous epithelial cells. Using a specific antimucin antibody, we found positive reactivity in $>75 \%$ of the cells in culture $(\mathrm{A}, \mathrm{C})$. There was no reactivity in the control cultures of both cell types (B, D). Bar, $100 \mu \mathrm{m}$.

cells isolated and cultured from human gastric biopsy specimens. A specific explanation for this difference was not readily apparent from our experiments. However, before being placed in the cell isolation media, we always stripped the surgical tissues of their underlying smooth muscle layers. This procedure was not possible with the gastric biopsies. We now know 

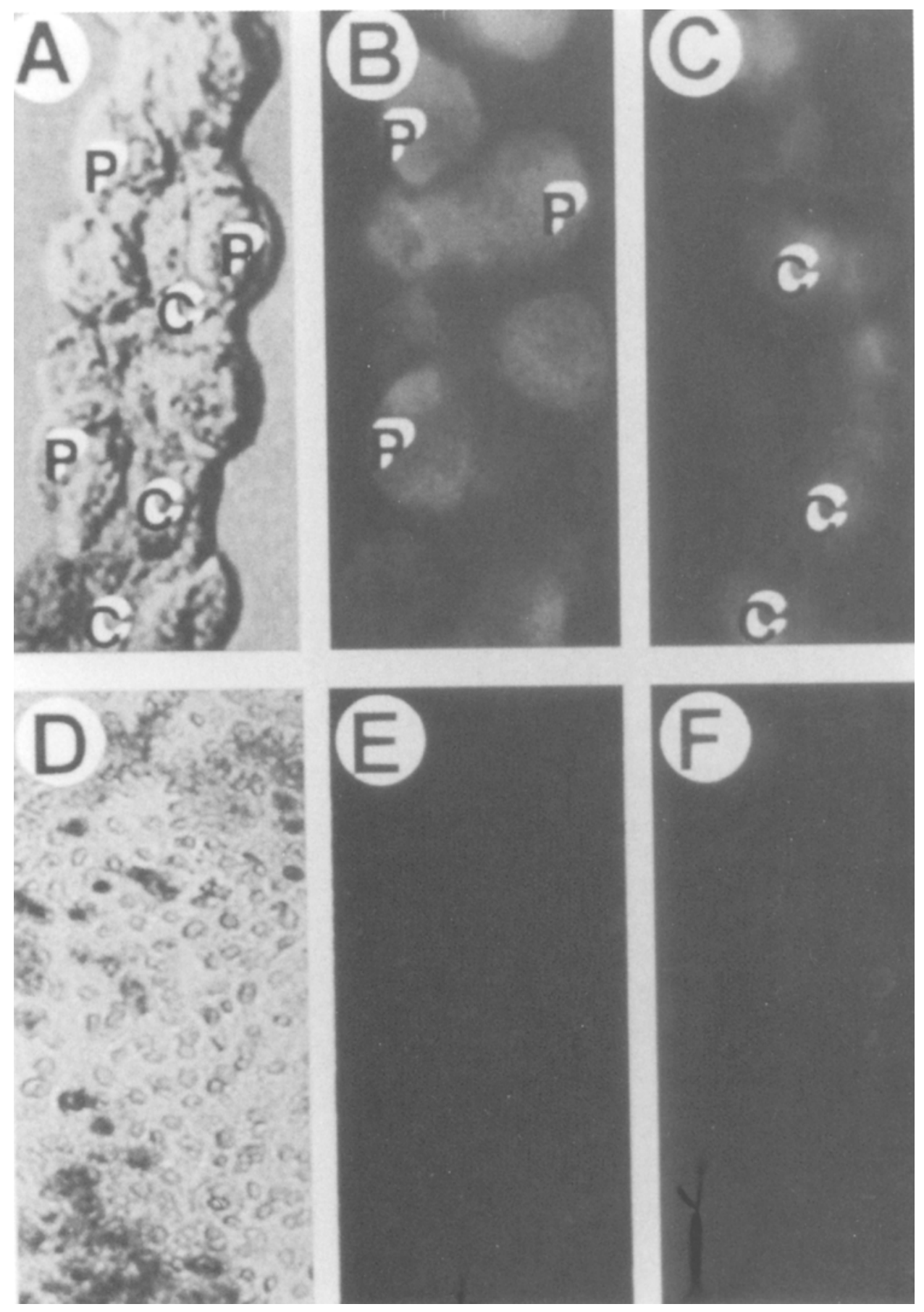

Figure 7. A representative series of phase and fluorescence mirographs showing positive immunostaining for the $\mathrm{I}^{+} / \mathrm{K}^{+}-$ ATPase in parietal cells (B), and positive immunostaining for pepsinogen in chief cells (C). A represents a phase contrast picture of a human gastric gland showing the bulging gastric parietal cells (P) with alternating gastric chief cells (C). D is a phase contrast picture of a human gastric mucous epithelial cell culture, with $\mathrm{E}, \mathrm{F}$ showing negative immunofluorescence for the $\mathrm{H}^{+} / \mathrm{K}^{+}$-ATPase and pepsinogen, respectively. $\times 200$.

that removal of the underlying muscle layer is critical in preventing mid-zone necrosis of gastric tissue [30]. The gastric biopsies used for our studies were taken with the smaller 'pinch-biopsy' forceps. This procedure may cause more trauma to the smaller stomach sample as compared to a larger piece of surgically resected tissue. Additional factors to account for the difference in cell growth between the two types of tissue specimens is the collagenase digestion proce- dure. With the surgical specimens we could scrape off the epithelial layer with a glass slide and then continue to mince the epithelial sheet before the collagenase digestion step. This ability to separate the epithelium from the underlying muscle layers was not possible with the smaller gastric biopsy samples. Instead, the biopsies were placed intact in the collagenase digestion media. With the surgical specimens, the collagenase enzymes have greater 

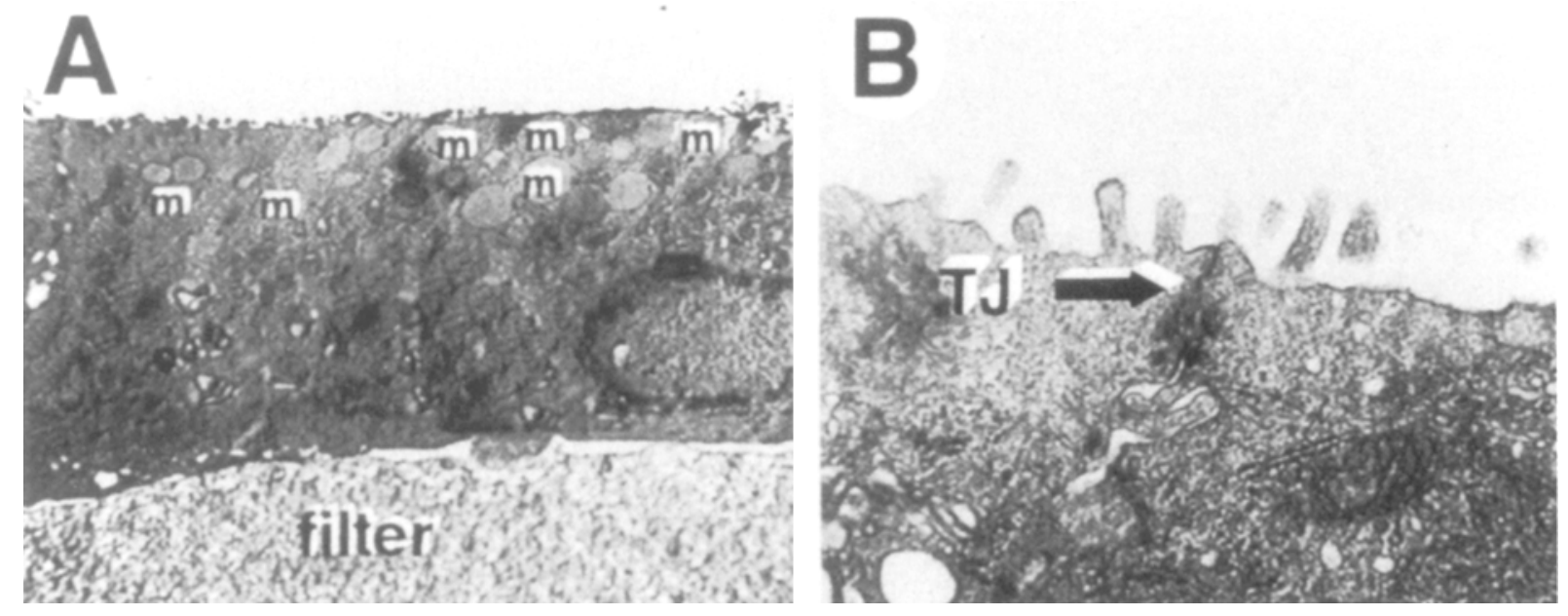

Figure 8. A is a representative low power electron micrograph of cultured human gastric mucous epithelial cells isolated from surgical specimens and grown on fibronectin-coated Falcon Cyclopore filter inserts. The cell culture monolayers were observed to be a single layer of polarized cuboidal epithelial cells, with apically located mucous granules ( $\mathbf{m}$ ), and short apical microvilli. B is an enlargement of an area of cells showing a close-up of the apical microvilli and the presence of tight junctions (TJ arrow). $\times 800$.

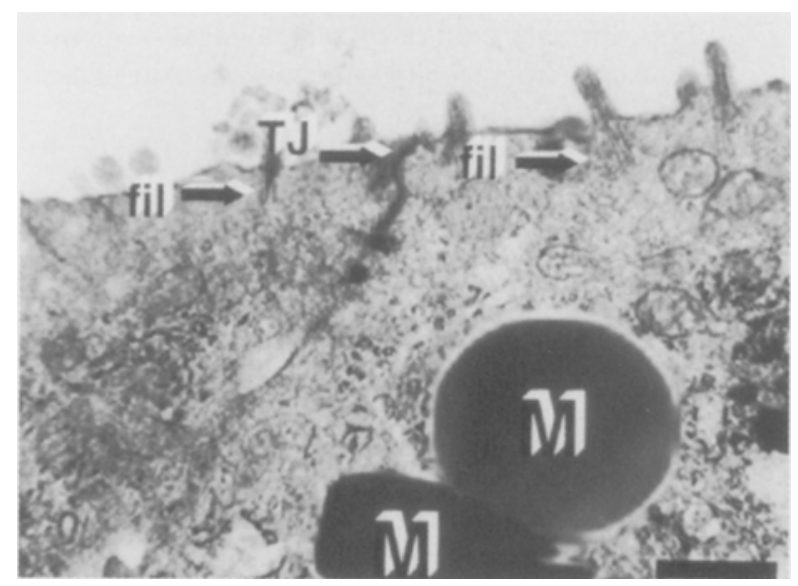

Figure 9. A high power electron micrograph of a human gastric mucous epithelial cell monolayer showing the details of the apical microvilli with underlying filaments (fil arrow), tight junction ( $\mathbf{T} \mathbf{J}$ arrow), and apically located mucous granules (M). These granules could positively be identified as containing mucin when the cultures were treated with $\mathrm{H}_{5} \mathrm{IO}_{6}$ and $\mathrm{TCH}$ with osmium for the electrochemical identification of mucin (see Section $3 \mathrm{C}$ ). $\times 800$.

access to several areas of the minced tissue which is likely to result in the isolation of a greater number of cells.

The combination of a porous filter coated with fibronectin increased the rate of attachment and growth of the gastric mucous epithelial cells. Of the matrix factors tested in this study, fibronectin was found to produce the best attachment, growth, and monolayer formation of human gastric mucous cells. Many authors have reported that fibronectin or collagen are good substrates for cell attachment in a variety of cultured gastric cells. These include guinea pig gastric mucous epithelial cells [27], rat gastric mucous epithelial cells $[11,36]$, fetal rabbit gastric epithelial cells [19], gastric chief cells [1, 8], and gastric parietal cells [9]. These effects are likely the result of the culture media having access to luminal and basolateral cell surfaces which is important for optimal epithelial cell growth and differentiation [7, $13,15]$. Also, one cannot underestimate the effects of other subtle factors on cell proliferation such as media $\mathrm{pH}$ which has been shown to have an effect on colon carcinoma cell growth [5].

In characterizing our cultures we found granules within the cells that stained positive for mucin and with an ultrastructure similar to mucous granules. These data are similar to well-characterized animal model systems of cultured canine gastric mucous epithelial cells [6, 32], hog gastric mucous cells [4], and guinea pig gastric mucous cells [4, 27, 29]. Electron microscopic analysis of the cultures also found the gastric mucous epithelial cells to be polarized, with apical microvilli and tight junctions. In summary, the protocol presented in our study provides a method toward obtaining large quantities of viable human gastric mucous epithelial cells for additional studies in gastric cell biology.

\section{Acknowledgments}

We would like to thank Patricia Harmon of the Kansas City VA Hospital for her excellent technical assistance. We would also like to thank the Kansas City VA Pathology Lab, and Eddie Robertson and Sandi Graham of the Portland Tissue Processing Lab for their help and advice on immunohistochemistry procedures. We would also like to thank Dr Adam Smolka for the anti- $\mathrm{H}^{+} / \mathrm{K}^{+}$ATPase antibody, and $\mathrm{Dr}$ I. Michael Smaloff for the antipepsinogen-1 antibody. Supported by a VA Merit Review Grant from the Department of Veterans Affairs. Dr C. Richard Boland's current address is: Division of 
Gastroenterology, Department of Medicine, MC-0688, 9500 Gilman Drive, University of California San Diego, La Jolla, CA 92093-0688, USA.

\section{Notes on suppliers}

1. Formal Scientific Inc., Box 649, Marietta, OH, 45750, USA

2. Nuaire Inc., 2100 Fernbrook Ln., Plymouth, MN 55447, USA

3. Nikon, Biomedical Group, 1300 Walt Whitman Road, Melville, NY 11747, USA

4. Beckman Instruments Inc., 2500 Harbor Blvd., Fullerton, CA 92634, USA

5. Fisher Scientific, P.O. Box 58056, San Francisco, CA 95059-8056, USA

6. Millipore Corp., 448 Grandview Drive, South San Francisco, CA 94080, USA

7. Coulter Electronics, 590 West Twentieth St., Hialeah, FL 33010, USA

8. Hoefer Scientific Instruments, 654 Minnesota St., San Francisco, CA 94107, USA

9. Gibco-BRL Life Technologies, P.O. Box 6009, Gaithersburg, MD 20897-8406, USA

10. Sigma Bio-Sciences, P.O. Box 14508, St Louis, MO 63178, USA

11. Celox Corporation, 856 South Fifth St., Hopkins, MN 55343, USA

12. Promega Corp., 2800 Woods Hollow Road, Madison, WI 53711-539, USA

13. Hyclone Laboratories, 1725 South Hyclone Road, Logan, UT 84321, USA

14. Pharmacia, 800 Centennial Ave., P.O. Box 1327, Piacataway, NJ 08855-1327, USA

15. Calbiochem/Oncogene Research, P.O. Box 12087, La Jolla, CA 92039-9958, USA

16. Boehringer-Mannheim Corp., 9115 Hague Road, P.O. Box 50414, Indianapolis, IN 46250-0414, USA

17. Dow Corning Corp., Dow Corning Ctr., Box 0994, Midland, MI 48686-0994, USA

18. Harlan Sprague-Dawley, Indianapolis, IN 46229 0176, USA

19. Radiometer of America, 810 Sharon Drive, Westlake, $\mathrm{OH} 44145$, USA

\section{References}

1. Akagi M, Yokozaki H, Kitadai Y, Ito R, Yasui W, Haruma K, Kajiyama G, Tahara E (1995). Expression of amphiregulin in human gastric cancer cell lines. Cancer 75(6 suppl): 1460-1466.

2. Ayalon AM, Sanders MJ, Thomas LP, Amirian DA, Soll AM (1982). Electrical effects of histamine on monolayers formed in culture from enriched canine gastric chief cells. Proc Natl Acad Sci USA 79: 7009-7013.

3. Barnard JA, Beauchamp RD, Russell WE, Dubois RN, Coffey RJ Jr (1995). Epidermal growth factor-related peptides and their relevance to gastrointestinal pathophysiology. Gastroenterol 108: 564-580.

4. Beinborn M, Giebel J, Linck M, Cetin Y, Schwenk M,
Sewing KF (1993). Isolation, identification and quantitative evaluation of specific cell types from the mammalian gastric mucosa. Cell Tissue Res 274: 229-240.

5. Bischof G, Cosentini E, Hamilton G, Riegler M, Zacherl J, Teleky B, Feil W, Schiessel R, Machen TE, Wenzl E (1996). Effects of extracellular pH on intracellular pH-regulation and growth in a human colon carcinoma cell-line. Biochem Biophys Acta 1282: 131-139.

6. Boland CR, Kraus ER, Scheiman JM, Black C, Deshmukh GD, Dobbins WO (1990). Characterization of mucous cell synthetic functions in a new primary canine gastric mucous cell culture system. Am J Physiol 258: G774-G787.

7. Cereijido M, Rotunno CA, Robbins ES (1978). Polarized epithelial membranes produced in vivo. In: JF Hoffman (ed), Membrane transport processes. New York: Raven Press.

8. Chen MC, Lee AT, Soll A (1991). Mitogenic response of canine fundic epithelial cells in short-term culture to transforming growth factor $\alpha$ and insulin-like growth factor. J Clin Invest 87: 1716-1723.

9. Chew CS, Ljungstöm M, Smolka A, Brown MR (1989). Primary culture of secretagogue-responsive parietal cells from rabbit gastric mucosa. Am J Physiol 256: G254-G263.

10. Defize J, Arwert F, Kortbeek H, Frants RR, Meuwissen SG, Eriksson AW (1985). Pepsinogen synthesis in monolayer culture of human and rabbit gastric mucosal cells. Virchows Arch [Cell Pathol] 49: 225-230.

11. Dial EJ, Kao Y-C J, Lichtenberger LM (1991). Effects of 16,16 -dimethyl prostaglandin $E_{2}$ on glycoprotein and lipid synthesis of gastric epithelial cells grown in a primary culture. In Vitro Cell Develop Biol 27A: 39-46.

12. Flemström G (1987). Gastric and duodenal mucosal bicarbonate secretion. In: LR Johnson (ed), Physiology of the gastrointestinal tract. New York: Raven Press, pp 351-369.

13. Freshney RL (1994). Culture of animal cells: A manual of basic technique, 3rd edn. New York: WileyLiss.

14. Halter $F$ (1991). Regeneration following gastric injury. In: JM Morisset, TE Solomon (eds), Growth of the gastrointestinal tract: Gastrointestinal hormones and growth factors. New York: CRC Press, pp 143-156.

15. Handler JS, Preston AS, Steele RE (1984). Factors affecting the differentiation of epithelial transport and responsiveness to hormones. Fed Proc 43: 2221-2224.

16. Hiraischi H, Terano A, Ota S, Mutoh H, Sugimoto T, Razandi M, Ivey KJ (1991). Oxygen metabolites stimulate mucous glycoprotein secretion from cultured rat gastric mucous cells. Am J Physiol 261: 662-668.

17. Johnson JP, Steele RE, Perkins FM, Wade JB, Preston AS, Green SW, Handler JS (1981). Epithelial organization and hormone sensitivity of toad urinary bladder cells in culture. Am J Physiol 241: F129-F138.

18. Lipkin M (1987). Proliferation and differentiation of normal and diseased gastrointestinal cells. In: LR Johnson (ed), Physiology of the gastrointestinal tract. New York: Raven Press, pp 255-284. 
19. Logsdon CD, Bisbee CA, Rutten MJ, Machen TE (1982). Fetal rabbit gastric epithelial cells cultured on floating collagen gels. In Vitro 18: 233-242.

20. Matuoka K, Tanaka M, Mitsui Y, Murota SI (1983). Cultured rabbit gastric epithelial cells producing prostaglandin $\mathrm{I}_{2}$. Gastroenterol 84: 498-505.

21. Miller LR, Jacobson ED, Johnson LR (1973). Effect of pentagastrin on gastric mucosal cells grown in tissue culture. Gastroenterol 64: 254-267.

22. Misfeldt DS, Hamamoto ST, Pitelka DR (1976). Transepithelial transport in cutlure. Proc Natl Acad Sci USA 7: $1212-1216$.

23. Moll R, Franke WW, Schiller DL, Geiger B, Krepler $R$ (1982). The catalog of human cytokeratins: patterns of expression in normal epithelia, tumors and cultured cells. Cell 31: 11-24.

24. Moyer MP (1983). Culture of human gastrointestinal epithelial cells. Proc Soc Exp Biol Med 174: 12-15.

25. Ota S, Razandi M, Sekhon S, Krause WJ, Terano A, Hiraishi H, Ivey KJ (1988). Salicylate effects on a monolayer culture of gastric mucous cells from adult rats. Gut 29: 1705-1714.

26. Pearse AGE (1989). Carbohydrates and mucosubstances: lipids, lipoproteins, and proteolipids. In: AGE Pearse (ed), Histochemistry: Theoretical and applied. New York: Churchill Livingston, Vol. 2, pp 675-849.

27. Rattner DW, Ito S, Rutten MJ, Silen W (1985). A rapid method for culturing guines pig gastric mucous cell monolayers. In Vitro Cell Develop Biol 21: 453-462.

28. Romano M, Razandi M, Sekhon SP (1988). Human cell line for the study of damage to gastric epithelial cells in vitro. J Lab Clin Med 111: 430-440.

29. Rutten MJ, Deempsey PJ, Solomon TE, Coffey RJ Jr (1993). TGF $\alpha$ is a potent mitogen for primary cultures of guinea pig gastric mucous epithelial cells. Am J PHysiol 265: G361-G369.

30. Rutten MJ, Ito S (1983). Morphology and eleectgrophysiology of guinea pig gastric mucosal repair in vitro. Am J Physiol 244: G171-G182.

31. Samloff IM (1971). Cellular localization of group 1 pepsinogens in human gastric mucosa by immunofluorescence. Gastroenterol 61: 185-188.

32. Scheiman JM, Kraus ER, Yoshimura K, CR Boland
(1992). Effect of sucralfate on components of mucosal barriere produced by cultured canine epithelial cells in vitro. Dig Dis Sci 37: 1853-1859.

33. Smolka A, Weinstein WM (1986). Immunoassay of pig and human gastric proton pump. Gastroenterol 90: 532-539.

34. Steele RE, Preston AS, Johnson JP, Handler JS (1986). Porous-bottom dishes for culture of polarized cells. Am J Physiol 251: C136-C139.

35. Stemmermann GN, Samloff IM, Hayashi T (1985) Pepsinogen I and II in carcinoma of the stomach: An immunohistochemical study. Appl Pathol 3: 159-163.

36. Terano A, Ivey KJ, Stachura J, Sekhon S, Hosojima $\mathrm{H}$, McKenzie WN Jr, Krause WJ, Wyche JH (1982). Cell culture of rat gastric fundic mucosa. Gastroenterol 83: 1280-1291.

37. Terano A, Mach T, Stachura J, Sekhon S, Tarnawski A, Ivey KJ (1983). A monolayer culture of human gastric epithelial cells. Dig Dis Sci 28: 595-603.

38. Tseng SC, Jarvinen MJ, Nelson WG, Huang JW, Woodcock-Mitchell J, Sun TT (1982). Correlation of specific keratins with different types of epithelial differentiation: Monoclonal antibody studies. Cell 30 : 361-372.

39. Yoshida K, Kyo E, Tsujino T, Sano T, Nimoto M, Tahara E (1990). Expression of epidermal growth factor, transforming growth factor- $\alpha$ and their receptor genes in human gastric carcinomas: Implications for autocrine growth. Jpn J Canc Res 81: 43-45.

40. Yoshida S, Kasuga S, Hirao Y, Fuwa T, Nakagawa S (1987). Effect of biosynthetic human epidermal growth factor on the synthesis of mucin glycoproteins from primary culture of rabbit fundal mucosa cells. In Vitro Cell Develop Biol 23: 460-464.

41. Zheng H, Shah PR, Audus K (1994). Primary culture of rat gastric epithelial cells as an in vitro model to evaluate antiulcer agents. Pharmaceutical Res 11: $77-82,1994$

Address for correspondence: Michael J. Rutten, PhD, Department of Surgery-L223A, 3181 Sam Jackson Park Road, Portiand, OR 97201, USA

Phone: (503) 494 1507; Fax: (503) 4948884

E-mail: ruttenm@ohsu.edu 